University of Nebraska - Lincoln

DigitalCommons@University of Nebraska - Lincoln

USDA National Wildlife Research Center - Staff Publications
U.S. Department of Agriculture: Animal and Plant Health Inspection Service

December 2006

\title{
Collisions of Red-tailed Hawks (Buteo jamaicensis), Turkey Vultures (Cathartes aura), and Black Vultures (Coragyps atratus) with Aircraft: Implications for Bird Strike Reduction
}

Bradley F. Blackwell

USDA/APHIS/WS National Wildlife Research Center, bradley.f.blackwell@aphis.usda.gov

Sandra E. Wright

United States Department of Agriculture, APHIS/WS

Follow this and additional works at: https://digitalcommons.unl.edu/icwdm_usdanwrc

Part of the Environmental Sciences Commons

Blackwell, Bradley F. and Wright, Sandra E., "Collisions of Red-tailed Hawks (Buteo jamaicensis), Turkey Vultures (Cathartes aura), and Black Vultures (Coragyps atratus) with Aircraft: Implications for Bird Strike Reduction" (2006). USDA National Wildlife Research Center - Staff Publications. 410.

https://digitalcommons.unl.edu/icwdm_usdanwrc/410

This Article is brought to you for free and open access by the U.S. Department of Agriculture: Animal and Plant Health Inspection Service at DigitalCommons@University of Nebraska - Lincoln. It has been accepted for inclusion in USDA National Wildlife Research Center - Staff Publications by an authorized administrator of DigitalCommons@University of Nebraska - Lincoln. 
J. Raptor Res. 40(1):76-80

(C) 2006 The Raptor Research Foundation, Inc.

\title{
Collisions of Red-tailed Hawks (Buteo jamaicensis), Turkey Vultures(Cathartes aura), and Black Vultures (Coragyps atratus) with Aircraft: Implications for Bird Strike Reduction
}

\author{
BRADLEY F. BLACKWELl ${ }^{\prime}$ \\ United States Department of Agriculture, Animal and Plant Health Inspection Service, Wildlife Services, National Wildife \\ Research Center, Ohio Field Station, 6100 Columbus Avenue, Sandusky, OH 44870 U.S.A.
}

\author{
SANDRA E. Wright \\ United States Department of Agriculture, Animal and Plant Health Inspection Service, Wildife Services, \\ 6100 Columbus Avenue, Sandusky, OH 44870 U.S.A.
}

KEY WoRDs: Black Vulture, Coragyps atratus; Red-tailed Hawk; Buteo jamaicensis; Turkey Vulture; Cathartes aura: airport, bird strike.

From 1990 through 2003, 52493 wildlife collisions with aircraft were reported to the U.S. Federal Aviation Administration (FAA); $97 \%$ of these incidents involved birds. The approximate cost to the civil aviation industry in the U.S.A. due to collisions of birds with aircraft (hereafter referred to as bird strikes) was $\$ 163.51$ million in direct monetary losses and associated costs for the 14yr period (Cleary et aI. 2004). Strikes with raptors (Falconidae and Accipitridae; including vultures, Cathartidae) accounted for approximately $28 \%$ of reported aircraft down time resulting from known-species bird strikes (known species $=182942 \mathrm{hr}$; intal for all hirds $=244510 \mathrm{hr}$ ) and represented a $\$ 12.9$ million loss to U.S. civil aviation (Cleary et al. 2004). However, these figures are misleading relative to actual costs; of 7265 reports of wildlife strikes involving damage to the aircraft, only 1759 reports provided cost estimates (Cleary et al. 2004).

Because of their size (at least six North Americannesting raptor species have a mean body mass $>1.8 \mathrm{~kg}$ ) and flight behavior (e.g., flocking or soaring), strikes with raptors pose a substantial threat to air safety relative to FAA airworthiness standards for airframes, windshields, and engines (Seamans et al. 1995, Dolbeer and Eschenfelder 2003). Recent work by Dolbeer (2006) shows that for bird strikes (1990-June 2003) $\leq 152.4 \mathrm{~m}$ above ground level (AGL), passerines, gulls/terns (Laridae), doves (Columbidae), and raptors (including vultures) were the species groups most frequently struck. For strikes $>152.4$ m AGL, waterfowl (Anatidae), gulls/terns, passerines, and vultures were the species groups most frequently struck. Notably, for strikes resulting in substantial damage to the aircraft (Dolbeer et al. 2000, Cleary et al. 2004), 66\% occurred at $\leq 152.4 \mathrm{~m}$ AGL (Dolbeer 2006).

\footnotetext{
1 Email address: Bradley.f.blackwell@aphis.usda.gov
}

More specifically, strikes involving Red-tailed Hawks (Buteo jamaicensis) comprised $24.5 \%$ of reported raptor strikes to civil aircraft from 1990-2003 ( $N$ strike reports involving raptors $=1945)$; strikes of Black Vultures (Coragyps atratus), Turkey Vultures (Cathartes aura), and inidentified vultures represented an additional $19.2 \%$ of reported raptor strikes (Cleary et al. 2004). Together, strikes of Red-tailed Hawks and vultures accounted for $93.4 \%$ of civilian aircraft down time associated with raptor strikes and represented a loss of dpproximately $\$ 7$ million to U.S. civil aviation over the 14 yr period (Cleary et al. 2004). Similarly, in an analysis of U.S. Air Force (USAF) strike data, Kelly (1999) reported that Red-tailed Hawks and Turkev Vultures accounted for the majority $(64 \%)$ of damaging raptor strikes by USAF aircraft (see also Lakrajsek and Bissonette 2005).

Because of the prominence of Red-tailed Hawks and vultures in military (Kelly 1999, Zakrajsek and Bissonette 2005) and U.S. civil aviation (Cleary et al. 2004) bird-strike clatabases, we questioned whether strike statistics might yield information critical to wildlife and resource management on the air operations area (AOA; areas designated for takeoff, landing, and surface maneuvers of aircraft) of an airport (14 CFR Part 139. Subpart D) and within FAA siting criteria for certificated airports (i.e., within $1.5 \mathrm{~km}$ of a runway for airports servicing piston-powered aircraft only and within $3.0 \mathrm{knu}$ of a runway for airports servicing turbine-powered aircraft; U.S. Federal Aviation Administration 2004). In general, an aircraft descending on a 3 glideslope would be $\leq 152.4 \mathrm{~m}$ AGL at $3.0 \mathrm{~km}$ from the runway (Flight Safety Foundation 2000)

Inportantly, we note that a strike report might involve more than one bird, only about $20 \%$ of wildlife strikes are reported, not all bird strikes are identified to species, the altitude of a strike is not always reported as $m$ AGL (i.e., the report might be relative to elevation of the airport), and bird strike-related damage and down-time costs are underreported (Cleary et al. 2004). Thus, species-specific losses and the associated costs to aviation due to those bird strikes are highly underrepresented by strike data within 
the FAA National Wildlife Strike Database. In addition, strike reports do not include data by which analyses can be standardized relative to aircraft type and the associated movements (i.e., takeoffs and landings) or hours in use prior to a strike. Our objective was to quantify U.S. civil aviation strike reports within the FAA National Wildlife Strike Database for Red-tailed Hawks, Black Vultures, Turkey Vultures, and unknown vultures relative to number of birds struck, season, and altitude

\section{METHOTS}

We used data from the FAA National Wildlife Strike Database for civil and joint-use airports (Cleary et al. 2004). The FAA uses a standard form $(5200-7)$ for voluntary reporting of wildlife strikes to civil aircraft in the U.S.A.; strike reports may also be made directly to the FAA National Wildlife Strike Database via the internet (Cleary et al. 2004). At the time of our analyses, the database contained 55329 strike reports from U.S. civil aviation (January 1990-19 July 2004). We included only reports where at least one bird was struck (i.e., we ignored reports of evasive action only) and assumed the minimum number of individuals struck when a range (e.g., 2-10 individuals) was reported in a single incident. In addition, we included strike reports for unknown vultures only when the report originated from a U.S. state or Canada, thus indicating that the bird was either a Turkey Vulture or Black Vulture.

The phase within a species' annual cycle (e.g., migration, iesting, incubation, nestling, or tledging) has been suggested as a possible factor contributing to the probability of a bird strike (Kelly 1999); however, assigning strikes to a specific phase is speculative at best because (1) nonbreeding birds are involved in strikes during the breeding season, and their behavior and habitat use might differ markedly from that of breeding adults, (2) not all individuals migrate (e.g., some Red-tailed Hawks are residents; Schafer et al. 2002), and (3) there is variation and overlap of the breeding chronology between years and with latitude (Preston and Beane 1993, Kirk and Mossman 1998, Buckley 1999, Kelly 1999). Therefore, we quantified the number of strikes and altitude of each strike by season (i.e., spring: 22 March-21 June; summer: 22 June-21 September; autumn: 22 September-2 1 December; winter: 22 December-21 March) within species group and inferred as to the probable phase within the annual cycle. We conducted $1 \times 4$ contingency table analyses using the chi-square test for goodness of fit (Conover 1980) to compare the number of strikes among seasons within each species group; we made our statistical comparisons at $\alpha=$ 0.025 (i.e., the 0.975 quantile of the chi-square random variable). To assess the degree to which hawk and vulture strikes might be mitigated via wildlife management methods on the AOA and within FAA siting criteria, we quantified the number of strikes by altitude of the strike.

\section{RFsLlts}

Red-tailed Hawks. For Red-tailed Hawks, we found 508 strike reports comprising 515 individuals struck by aircraft across 40 states and the District of Columbia; 7 strikes involved at least 2 birds. Over $49 \%$ of the strikes occurred in [llinois (19.5\%), Oregon (14.2\%), California

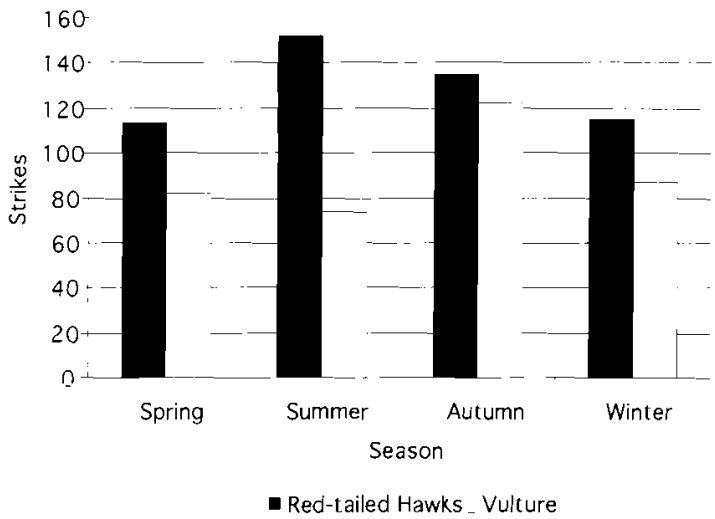

Figure 1. Strike reports by the L.S. civil aviation industry (January 1990-19 July 2004) involving Red-tailed Hawks, Turkey Vultures, Black Vultures, and unknown vultures were taken from the FAA National Wildlife Strike Database and depicted by season.

(10.4\%), and Pennsylvania (5.3\%). Although more strikes occurred during summer, we found no statistical difference in the number of Red-tailed Hawks struck by season $\left(\bar{x}=128.8\right.$ strikes, $\mathrm{SD}=18.4$ strikes: $\chi^{2}=7.9,0.975$ quantile $=9.348 . P=0.048, \mathrm{df}=3$; Fig. 1). Further, when time of day was reported, $95 \%$ of strikes occurred during daylight hours $($ dawn $=18$ strikes; day $=24 \overline{7}$ strikes; dus $\dot{k}$ $=15$ strikes; night $=14$ strikes; unknown $=214$ strikes) . In addition, $82 \%$ of strikes occurred at or below $30.5 \mathrm{~m}$ AGL, whercas nearly $63 \%$ occurred while the aircraft was operating on the ground (Table 1).

Vultures. For vultures, we found 334 reports comprising 365 individuals struck by aircraft and representing the loss of 193 Turkey Vultures, 24 Black Vultures, and 148 unidentified vultures; 31 strikes involved at least 2 birds. Vultures werc struck in 29 states, the District of Columbia, Mexico, Brazil, and Guatemala; $54.0 \%$ of the strikes occurred in Florida, followed by unknown points (i.e., en route; $9.0 \%)$, California $(8.4 \%)$, and Texas $(6.6 \%)$. When time of day was reported, $99 \%$ of strikes occurred during daylight hours $($ dawn $=2$ strikes; day $=259$ strikes; dusk $=$ 3 strikes; night $=3$ strikes; unknown $=67$ strikes). Also, strikes were more frequent during autumn $(\bar{x}=91.2$ strikes, $\mathrm{SD}=21.2$ strikes; $\chi^{2}=14.8,0.975$ quantile $=$ 9.348, $P=0.002$, df $=3$; Fig. 1 ). $\ln$ addition, approximately $29 \%$ of strikes occurred at or below $30.5 \mathrm{~m}$ AGL, whereas $17 \%$ occurred while the aircraft was operating on the ground (Table 1).

\section{Discussion}

Most $(63 \%)$ strikes involving Red-tailed Hawks occurred on the ground (Table 1). Further, we found that strikes were, on an absolute scale, more frequent during summer months, corresponding to a period when newly fledged birds were common in the population (Preston and Beane 1993, Dolbeer 2006). Surprisingly, even during summer, 
Table 1. Bird strike reports by the L.S. civil aviation industry (January 1990-19 June 2004) involving Red-tailed Hawks. Turkey Vultures, Black Vultures, and unknown vultures were taken from the FAA National Wildlife Strike Database and categorized by altitude (i.e., m above ground level; AGL).

\begin{tabular}{|c|c|c|c|c|c|c|}
\hline \multirow[b]{2}{*}{$\begin{array}{r}\text { Aititude } \\
(\text { AGL })^{\mathrm{a}}\end{array}$} & \multicolumn{3}{|c|}{ Red-TaIILD HatuKs } & \multicolumn{3}{|c|}{ VIITLRES } \\
\hline & $\begin{array}{l}\text { No. Bikes } \\
\text { StRl ick }\end{array}$ & $\begin{array}{c}\text { Percent at KYOWX } \\
\text { Ainitl teb }\end{array}$ & $\begin{array}{l}\text { PerreNT OF } \\
\text { TOTAL }\end{array}$ & $\begin{array}{l}\text { No. Biris } \\
\text { Strceck }\end{array}$ & 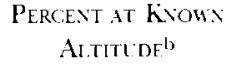 & $\begin{array}{l}\text { PERCENT OF } \\
\text { TOTAI }\end{array}$ \\
\hline 0 & 185 & 62.9 & 35.9 & 55 & 17.0 & 15.1 \\
\hline $0.3-30.5$ & 57 & 19.4 & 11.1 & 38 & 11.8 & 10.4 \\
\hline $30.8-152.4$ & 28 & 9.5 & 5.4 & 64 & 19.8 & 17.5 \\
\hline $152.7-304.8$ & 9 & 3.1 & 1.7 & 63 & 19.5 & 17.3 \\
\hline $305.1-609.6$ & 9 & 3.1 & 1.7 & 72 & 22.3 & 19.7 \\
\hline $609.9-914.4$ & 2 & 0.7 & 0.4 & 20 & 6.2 & 5.5 \\
\hline $914.7-1219.2$ & 1 & 0.3 & 0.2 & 8 & 2.5 & 2.2 \\
\hline $1219.5-1524.0$ & 1 & 0.3 & 0.2 & 2 & 0.6 & 0.5 \\
\hline$>1524.0$ & 2 & 0.7 & 0.4 & 1 & 0.3 & 0.3 \\
\hline Unreported & 221 & & 42.9 & 42 & & 11.5 \\
\hline Total & 515 & 100 & 100 & 365 & 100 & 100 \\
\hline
\end{tabular}

"International civil aviation standirds require altitude to be reported in units of "feet," units from which the AGL intervals were converted.

h Percent of the total number of strikes less strikes at unreportod altitudes.

where thermal conditions would be conducive to soaring, $84 \%$ of strikes occurred below $30.5 \mathrm{~m}$ AGL. These results are indicative that managenent of food avalability and abundance and vegetation structure on airports could reduce airfield use by resident hawks, as well as birds inexperienced in both hunting and avoiding air traffic. However, we note that our findings relative to season of strike contrast with work by Kelly (1999), who showed that strikes involving Red-tailed Hawks and CSAF aircraft were more likely during spring, corresponding to migration and the incubation phasc of the breeding period. A likely reason for this difference in seasonality of strikes is that the FAA Wildlife Strike Database comprises records of strikes to civil aircraft and flight movenents that differ markedly in speed, location, and altutude from those of military aircraft.

For strikes involving vultures, most $(68 \%)$ occurred at or below $305.0 \mathrm{~m} \mathrm{AGL}$, altitudes similar to mean soaring altitudes for Black and Turkey nultures $(169 \mathrm{~m}, \mathrm{SD}=115$ and $163 \mathrm{~m}, \mathrm{SD}=92$, respectively) over forested habitat (DeVault et al. 2005). Also, we showed that $88.9 \%$ of vulture strikes, when the species was identified, involved Turkey Vultures, a soaring species (Kirk aud Mossman 1998). However, we note that a surprising number of vulure strikes ( $17 \%$ ) occurred during ground operations.

Our findings relative to the seasonality of vulture strikes (peaking in autumn) contrast to those reported for LSAF aircraft (Kelly 1999), in which strikes with Turkey Vultures were more frequent during summer, when fledged birds had entered the population and thermals were prevalent. We suggest that our findings regarding seasonality of strikes relate to autumn migration and contrast to kelly's
(1999) findings, again, because aircraft and air operations differ substantially between civil and military aviation.

Management programs io reduce biru strikes have traditionally concentrated efforts on vegetation structure and other resources (e.g., removing harborage) at airports, but also integrated non-lethal harassment and lethal control on the AOA (Cleary and Dolbeer 2005). Dolbeer's (2006) findings further emphasize the need to focus wildlife-management efforts on the AOA to reduce bird strikes. However, with regard to raptors, particularly large $(>1.8 \mathrm{~kg})$ soaring species, the relationship between management on and near the AOA and the potential for a reduction in strikes has been speculative. Our analysis of strike records for Red-tailed Hawks and vultures, species groups prominent in raptor strikc statistics (Cleary et al. 2004), suggested that management efforts to both reduce food resources and habitat availability on the AOA could reduce strike frequency.

Specifically, the reduction of raptor food resources on and near the AOA, particularly rodent populations and carrion (e.g., road-killed animals), is likely critical to controlling foraging by both Red-tailed Hawks and inltures (e.g., Baker and Brooks 1981, Coleman and Fraser 1987, DeVault et al, 2003. Cleary and Dolbeer 2005). The open airport enviroument and its associated high road density might increase food resource abundance, particularly for vultures (e.g., road-killed animals: Coleman and Fraser 1987), as well as increasing thermal updrafts conducive to soaring. For example, Coleman and Fraser (1989) found that home ranges for both Turkey and Black vuluures included roads and open habitat in a greater proportion than available within their study area 
(also see DeVault et al. 2004). Further, DeVault et al. (2005) theorized that daily diet preferences, foraging

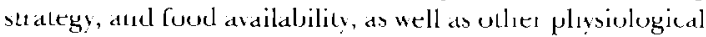
and social factors, figured more prominently in vulture flight behavior than clinatic variables. Therefore, we suggest that imely remosal of road-killed animals will reduce vulture foraging activity and, likely, frequency of soaring through AOAs.

We suggest that airport managers should strive toward an integrated management approach that comprises, in addition to control of food resources. the reduction of perching, loafing, nesting, and roosting habitats (e.g., Coleman and Fraser 1989, Avery et al. 2002, Seamans 2004) on AOAs (Schafer et al. 2002, Teague 2002) and. where necessary, on bordering properties (14 CFR Part 139, Subpart D; Cleary and Dolbeer 2005; Transport Canada 2001; U.S. Federal Aviation Administration 2004. Cleary and Dolbeer 2005). For example, there is evidence that Red-tailed Hawk distribution is linked to a composite of prey, low-density plant cover (i.e., vegetation that increases vulnerability of rodents to predation), and perch availability (Preston 1990). Leyhe and Ritchison (2004) reported similar findings, noting the importance of perches to foraging Red-tailed Hawks in association with use of habitats characterized by low-density plant cover. Therefore, a particular management emphasis for the AOA, within vegetation cover types characterized by lowdensity plant coverage, should be the control of perching on runway signage and structures proximate to taxiways and runways (see U.S. Federal Aviation Administration 9no4)

We emphasize that control of a single habitat feature (e.g., perching sites) on airports, withont an integrated wildlife management approach that targets food and other habitat resources, will not necessarily reduce exploitation by hawks and vultures of thernal conditions conducive to aerial foraging. A current habilat-management protocol under consideration for arports and complimentary to reduction in perching. loafing, and roosting habitats is use of tall fescue (Festura arundinacea; Clcary and Dolbeer 2005), a sod grass of temperate euvironments. Varietics of tall fescue. if infected with the fungus, Neolyphodium cornophialum. may be repellent to small mammals (Coley et al. 1995, Conover 1998).

With increasing air traffic world-wide and quieter aircraft with fewer engines, the potential for loss of hmman lives, property, and birds due to bird strikes is increasing (Cleary et al. 2004, Cleary and Dolbeer 2005). Reducing the potential for bird strikes requires proactive, integrative, and collaborative wildlife management measures involving airport administrations, municipalities, private groups, government agencies, and professional wildlife biologists.

COLISIONES DE BLTEO JAMAICENSIS, CATHARTES AURA Y CORAGYPS ATRATLS CON AERONAVES:
CONSECLENCIAS PARA LA REDLCCIÓN DE LOS GOLPES POR AVES

RFSLVI: $\backslash-B u t e o$ jamaicensis, Calhartes aura y Coragyps atratus estuvieron involucrados en aproximadamente el $37 \%$ de los golpes de rapaces $(N=1945)$ que se registraron contra aviones civiles en los EELL' entre 1990 y 2003 , resultando en un $93.4 \%$ del tiempo en que los aviones se encontraron fuera de servicio debido a golpes de rapaces en general, y en una pérdida de aproxiuradamente $\$ 7$ millones para la industria aérea civil de EEUL. Nos preguntamos si las estadisticas de los golpes de rapaces podrían brindar información crítica para el manejo de la vida silvestre y de los recursos en las áreas de operación (AAO; áreas designadas para el despegue, aterrizaje. y maniobras terrestres de los aviones) de los aeropuertos y dentro del área establecida por la Administración Federal de Aviación de EELL (AFA) para los aeropuertos certificados (i.e., hasta $1.5 \mathrm{~km}$ desde la pista para los aeropuertos que operan solamente con aviones con propulsión a piśón y de $3.0 \mathrm{~km}$ desde la pista para acropuertos que operan aviones con propulsión a turbina). Ninestro objetio fue cuantificar los informes de golpes a la aviación civil de EEUL usando la base de datos de golpes contra vida silvestre de la AFA (1990-2004) que hayan incluido a $B$. jamairensis, C. aura, C. atratus y buitres no identificados. Luego relacionamos esta información con el nimero de aves golpcadas, la cstación y la altitud. Encontramos que el $82 \%$ de los golpes que involucraron a $B$. jamaicansis se dieron hasta o por debajo de $30.5 \mathrm{~m}$ sobre el nivel del suelo (SNS; dentro de los límites de las AAO), y cerca del $63 \%$ se dieron mientras los aviones estaban operando en el suclo. Del mismo modo, encontramos que aproximadamente el $29 \%$ de los golpes que involucraron a buitres se dieron hasta o por debajo de $30.5 \mathrm{~m}$ SNS, con un $17 \%$ ocurrido mientras los aviones estaban operando en el suelo. No hubo una diferencia estacional dentro de los grupos de especies en el número de halcones o buitres golpeados. Sugcrimos que los esfuerzos de nanejo que reducen los recursos alimenticios de las rapaces en las $\mathrm{AAO}$, así como los esfuerzos que reducen los lugares de percha, descanso, nidificación y refugio nocumo dentro de estas áreas, pueden mejorar la seguridad de la aviación y redıcir las colisiones.

[Traducción del equipo editorial]

\section{ACKNOWLEDGMENTS}

We greatly appreciate reviews of earlier drafts of this manuscript by M.L. Avery, R.C. Beason, T.L. DeVault, R.A. Dolbeer, J. Gehring, M.S. Lowney, and T.W. Seamans. Our work was supported by the U.S. Department of Agriculture, Animal and Plant Health Inspection Service, Wildlife Services (WS), WS National Wildlife Research Center, and the FAA, William Hughes Technical Center, Allantic City. New Jersey, under agreement DTFACT-()4-X-90003. Opinions expressed in this study do not necessarily reflect current FAA policy decisions regarding the control of wildlife on or near airports. 
Litf.rttl Re Cutfod

Aiery, M.L., J.S. Humphrfy, E.A. Tillman, K.O. Phares, alid J.E. Hatcher. 2U02. Dispersing vulture roosts on communication towers. J. Raptor Res. 36:45-50.

Baker, J.A. NWD R.J. Brooks. 1981. Raptor and vole populations at an airport. J. Wildl. Manage. 45:390-396.

BLCKI.FY, N.J. 1999. Black Vulture (Coragyps atratus). In A. Poole and F. Gills [EDs.], The birds of North America, No. 411. The Birds of North America, Inc. Philadelphia, PA U.S.A.

Cleary, E.C. aNo R.A. Dolbeer. 2005. Wildlife hazard management at airports, 2nd Ed. Federal Aviation Administration, Office of Airport Safety and Standards, Airport Safety and Compliance Branch, Washington, DC U.S.A.

- —, AND S.E. WRIGHT. 2004. Wildlife strikes to civil aircraft in the United States 1990-2003. U.S. Department of Transportation, Federal Aviation Administration, National Wildlife Strike Database Serial Report Number 10. Office of Airport Safety and Standards, Airport Safety and Certification, Washington. DC L'S.A. http://wildlife-mitigation.tc.faa.gov/ public_hmıl/. Last access 15 October 2005.

Colfman, J.S. And J.D. Fraser. 1987. Food habits of Black and Turkey vultures in Pennsylvania and Maryland. $f$. Wildl. Manage. 51:733-739.

- AND 1989 . Habitat use and home ranges of Black and Turkey vultures. J. Wildl. Manage. 53:782-792.

Colfy, A.B., H.A. Fribourc, M.R. Pelton, and K.D. Gwinn. 1995. Effects of tall fescuc endophyte infestation on relative abundance of small mammals. J. Environmental Quality 24:472-475.

Conover, M.J. 1998. Impact of consuming tall fescue leaves with the endophytic fungus, Acremonium coenophialum, on meadow voles. J. Mammal. 79:79:457-463.

Conover, W.J. 1980. Practical nonparametric statistics, 2nd Ed. John Wiley and Sons, New York, NY U.S.A.

DeVaul.t, T.L., B.D. Reinhart, I.L. Brisbin, Jr, and O.E. RHoDes, JR. 2004. Home ranges of sympatric Black and Turkey vultures in South Carolina. Condor 106: $706-711$.

$\longrightarrow, \longrightarrow$, $\longrightarrow$, 2005. Flight behavior of Black and Turkey vultures: implications for reducing bird-aircraft collisions. J. Wildl. Manage. 69:592-599.

, O.E. Rhodes, JR., ANI J.A. SHIvtK. 2003. Scavenging by vertebrates: behavioral, ecological, and evolutionary perspectives on an important energy transfer pathway in terrestrial ecosystems. Oikos 102:225-234.

DolbfFr, R.A. 2006. Height distribution of birds as recorded by collisions with civil aircraft. J. Wildl. Manage. In press.
— AND P. Eschenfelder. 2003. Amplified bird-strike risks related to population increases of large birds in North Amcrica. Proc. Intl. Bird Strihe Comm. 26:19 67.

- S.E. WRIGHT, AND E.C. CI.FARY. 2000. Ranking the hazard level of wildlife species to aviation. Wildl. Soc. Bull. 28:372-378.

Flight Safety Foundatios, 2000. Flight Safety Foundation approach-and-landing accident reduction briefing note 4.2-energy management. Flight Safety Digest. AugustNovember:75-80.

KFLLY, T.A. 1999. Seasonal variation in birdstrike rate for two North American raptors: Turkey Vulture (Cathartes aura) and Red-tailed Hawk (Buteo jamaicensis). J. Raptor Res. 33:59-62.

Kirk, D.A. AND M.J. Mossman. 1998. Turkey Vulture (Cathartes aura). In A. Poole and F. Gills [Eos.], The Birds of North America, No. 339. The Birds of North America, Inc. Philadelphia, PA U.S.A.

L_FyHF, J.E. AND G. Rrtchison. 2004. Perch sites and hunting behavior of Red-tailed Hawks (Buteo jamaicensis). J. Raptor Res. 38:19-25.

Preston, C.R. 1990. Distribution of raptor foraging in relation to prey biomass and habitat structure. Condor 92:107-112.

- ANI) R.D. BEANE. 1993. Red-tailed Hawk (Buteo jamaicensis). In A. Poole and F. Gills [EDs.], The Birds of North America, No. 52. The Birds of North America, Inc. Philadelphia, PA U.S.A.

Schafer, L.M., J.L. Cummings, J.A. Ylinger, and K.E. Gustad. 2002. Evaluation of raptor translocation at O'Hare International Airport, Chicago, Illinois. Final report to FAA, William Hughes Technical Center, Atlantic City, NJ U.S.A., under agreement DTFA03-99-X-90001.

Seamans, T.W. 2004. Response of roosting Turkey Vultures to a vulture effigy. Ohio /. Sci. 104:136-138.

—_ D.W. Hamfrsho(K, and G.E. Bernhardt. 1995. Determination of body density for twelve bird species. Ibis 137:425-428.

TLAGLE, D.D. 2002. Vulture roost dispersal-improving air safety at Eglin Air Force Base. Flying Safety 58:22-25.

Travsport Canada. 2001. Sharing the skies. An aviation industry guide to the management of wildlife hazards. Transport Canada Aviation Publishing Division, Ottawa, Ontario, Canada.

U.S. Froeral Aviation Admintstration. 2004. Hazardous wildlife autractants on or near airports. Advisory Circular No: $150 / 5200-33 A$.

ZAKRAJSEK, E.J. AND J.A. BissonetTF. 2005. Ranking risk of wildlife species hazardous to military aircraft. Wildl. Soc. Bull. 33:258-264.

Received 19 November 2004; accepted 26 September 2005 